\title{
Review
}

\section{Second root and second root canal prevalence in maxillary first and second premolars assessed by cone beam computed tomography - a systematic review and meta-analysis}

\author{
Jorge N.R. Martins ${ }^{a, b, *}$, Duarte Marques ${ }^{a, b, c}$, Emmanuel João Nogueira Leal Silva ${ }^{d, e}$, \\ João Caramês ${ }^{a, b, c}$, António Mata ${ }^{a, c}$, Marco A. Versianif \\ ${ }^{a}$ Centro de Estudo de Medicina Dentária Baseada na Evidência, Faculdade de Medicina Dentária, Universidade de Lisboa, Portugal \\ ${ }^{b}$ Instituto de Implantologia, Lisboa \\ ${ }^{c}$ LIBPhys-FCT UID/FIS/04559/2013, Lisboa \\ ${ }^{d}$ Department of Endodontics, School of Dentistry, Grande Rio University, Rio de Janeiro, Brazil \\ ${ }^{e}$ Department of Endodontics, Rio de Janeiro State University, Rio de Janeiro, Brazil \\ f Dental Specialty Center, Brazilian Military Police, Minas Gerais, Brazil
}

\section{A R T I C L E I N F O}

\section{Article history:}

Received 22 July 2019

Accepted 4 September 2019

Available online 10 September 2019

\section{Keywords:}

Anatomy

Cone-beam computed tomography

Maxillary premolar

Meta-analysis

Systematic review

\begin{abstract}
A B S T R A C T
The aim of this systematic review was to assess the influence of demographic factors (gender, geographic region and age) on the prevalence of a second root and a second root canal in the maxillary first and second premolars by means of cone beam computed tomography. Four electronic databases and five peer-review journals were evaluated. Bibliographic references were screened and the authors contacted. Scientific merit assessment was performed by two independent observers using the Joanna Briggs Institute Critical Appraisal tool. Overall proportions and odds ratio forest plot were calculated and meta-regression performed to assess study heterogeneity. The review methodology protocol was registered before the study in PROSPERO. Nine studies were selected and data from 8,180 teeth (4,230 first premolars and 3,950 second premolars) were evaluated. The global proportion of a second root and second root canal were $43.2 \%$ and $77.2 \%$ for the first premolar, and $8.5 \%$ and $43.9 \%$ for the second. Tooth type, gender and geographic region in a comparison between groups revealed significant differences in the primary outcomes. (Rev Port Estomatol Med Dent Cir Maxilofac. 2019;60(2):37-50)
\end{abstract}

(C) 2019 Sociedade Portuguesa de Estomatologia e Medicina Dentária. Published by SPEMD. This is an open access article under the CC BY-NC-ND license (http://creativecommons.org/licenses/by-nc-nd/4.0/).

\footnotetext{
* Corresponding author.

E-mail address: jnr_martins@yahoo.com.br (Jorge N.R. Martins).

http://doi.org/10.24873/j.rpemd.2019.09.451

1646-2890/@ 2019 Sociedade Portuguesa de Estomatologia e Medicina Dentária. Published by SPEMD.

This is an open access article under the CC BY-NC-ND license (http://creativecommons.org/licenses/by-nc-nd/4.0/).
} 


\title{
Prevalência da Segunda Raiz e Segundo Canal Radicular nos Primeiros e Segundos Pré-molares Maxilares Analisados por Tomografia Computorizada de Feixe Cónico - Revisão Sistemática com Meta-Análise
}

\author{
R E S U M O
}

\section{Palauras-chave:}

Anatomia

Tomografia computorizada

de feixe cónico

Pré-molar maxilar

Meta-análise

Revisão sistemática
O objetivo da atual revisão foi analisar a prevalência de uma segunda raiz e segundo canal radicular (objetivos primários) nos primeiros e segundos pré-molares maxilares analisados por tomografia computorizada de feixe cónico, e avaliar a influência de fatores demográficos (género, região geográfica, e idade) nos resultados obtidos. Foram pesquisadas quatro bases de dados eletrónicas e cinco revistas científicas com revisão por pares. As referências bibliográficas foram pesquizadas e os autores contactados. O mérito científico dos trabalhos foi aferido por dois observadores independentes usando o Joanna Briggs Institute Critical Appraisal tool. Foram realizados forest plots de proporções e de odds ratio. A heterogeneidade foi avaliada por meta-regressão. A metodologia da pesquisa foi previamente registada no PROSPERO. Foram selecionados 9 estudos que reportam dados relativos a 8,180 dentes $(4,230$ primeiros pré-molares e 3,950 segundos pré-molares). A prevalência global de uma segunda raiz e segundo canal foi de $43,2 \%$ e $77,2 \%$ para o primeiro pré-molar, e $8,5 \%$ e $43,9 \%$ para o segundo. Comparações entre grupos relativos ao tipo de dente, género e regiões geográficas revelaram diferenças significativas nos objetivos primários. (Rev Port Estomatol Med Dent Cir Maxilofac. 2019;60(2):37-50)

(C) 2019 Sociedade Portuguesa de Estomatologia e Medicina Dentária. Published by SPEMD. This is an open access article under the CC BY-NC-ND license (http://creativecommons.org/licenses/by-nc-nd/4.0/).

\section{Introduction}

Differences in the root and root canal system are evident in all groups of teeth. ${ }^{1,2}$ Research regarding tooth morphology is essential in order to achieve an adequate debridement and disinfection during root canal treatment procedures, which in turn improves the prognosis of the endodontic therapy. ${ }^{3,4}$ In the literature, root and root canal morphologies have been addressed using a number of techniques including diaphanization, $^{2}$ sectioning, ${ }^{5}$ and micro-computed tomography (micro-CT). ${ }^{6}$ Amongst imaging techniques to perform in vivo assessment of the root canal morphology, CBCT has been proved to be the most reliable, ${ }^{7}$ making it also the preferred tool for measuring the influence of epidemiological parameters on the anatomy of root and root canal in large sub-populations. ${ }^{8,9}$ Understanding how demographic factors may influence the anatomy of different groups of teeth may help clinicians in anticipating the presence of more complex anatomical morphologies in the clinical setting.

Previous anatomical studies on maxillary first and second premolars reported different variations in both number of roots and root canals. In the maxillary first premolar, a 2-root configuration is the most common morphology, with several ex vivo and in vivo studies reporting averages above 52\%, $10-12$ while a 3 -rooted morphology was reported from $1.3 \%^{12}$ to $6.0 \%{ }^{11}$ of the cases. The presence of furcation grooves have also been observed in these teeth ${ }^{13}$ and correlated with changes in their internal anatomy. In terms of root canal configuration, Vertucci's Type IV seems to be the most common configuration. ${ }^{2,10,12}$ A high prevalence of lateral canals has been documented as being as high as $49.5 \%$ in maxillary first premolars, ${ }^{2}$ mostly at the apical area. ${ }^{2,12}$ On the other hand, a single root is the most common root morphology observed in maxillary second premolars ${ }^{12,14,15}$ with percentage frequencies above $67.0 \%$, while 3-rooted configurations is an uncommon finding. ${ }^{12,14} \mathrm{~A}$ micro-CT study ${ }^{15}$ reported that Vertucci's Type IV and $\mathrm{V}$ were the most common observed canal configurations, a result which was in line with an in vivo CBCT study. ${ }^{14}$ However, this result is not in accordance to other studies that demonstrated Vertucci's Type $\mathrm{I}^{10,12}$ to be the most common configuration. Lateral canals in these group of teeth have also a high prevalence (59.5\%), ${ }^{2}$ once again, more commonly located at the apical level. ${ }^{2,12}$

To our knowledge, there are no previous reviews of epidemiological studies addressing demographic factors that may have influence the presence of a second root and a second root canal in maxillary premolars. Therefore, the aim of this review was to systematically assess the proportions of a second root and a second root canal in maxillary first and second premolars in in vivo conditions by evaluating CBCT prevalence studies and to assess the influence of gender, age and geographic region in the final outcomes. The influence of voxel size imaging used in the selected studies to detect these anatomical features was also taken into account. The present review question followed the Condition, Context, Population format (CoCoPop) for prevalence studies reviews and was stated as: "What is the prevalence of a second root and a second root canals in maxillary premolars in patients undergoing CBCT?" The null hypotheses to be tested in this review were that there was no significant difference between (a) teeth groups, (b) gender, (c) geographic region, and (d) age regarding the proportions of the second root and second root canal in maxillary premolars. 


\section{Material and Methods}

\section{Protocol and registration}

The methodology applied in this review was accepted and registered in PROSPERO (CRD42019133352) prior to the study and was designed taking into consideration the PRISMA (Preferred Reporting Items for Systematic Review and Meta-Analysis) statement. ${ }^{16}$

\section{Search sources and strategy}

Four electronic databases were screened (PubMed, ScienceDirect, Lilacs and Cochrane Collaboration) in order to identify all relevant prevalence studies on maxillary first and second premolar roots and root canal configurations assessed by means of CBCT technology. The terms and filters used in each electronic source are summarized in Table I. Three peer-reviewed endodontic journals (Journal of Endodontics, International Endodontic Journal and Australian Endodontic Journal), two peer-reviewed evidence-based journals (Evidence Based Dentistry and Journal of Evidence-Based Dental Practice) and all references of the relevant studies were manually searched. The authors from the relevant studies were also contacted via email and asked if any additional information was available, whether as a format of scientific articles, thesis or grey literature.

\section{Study selection and eligibility criteria}

The studies included followed a "3 stage assessment". Initially, all titles and abstracts were accessed and, taking into account pre-defined inclusion/exclusion criteria (Table II), were classified as 'relevant', "possibly-relevant" or 'irrelevant'. In the second stage, the full-text of the relevant and possibly-relevant papers were analyzed and re-categorized following the same criteria. In the final stage, only the relevant papers were submitted to a scientific merit assessment.

\section{Scientific merit assessment}

A critical appraisal taking into account the scientific merit of the selected studies was performed by using the Joanna

\begin{tabular}{|c|c|}
\hline Code & Inclusion \\
\hline IA & Evaluation under СВСТ \\
\hline IB & Brand of СВCT machine is given \\
\hline IC & Voxel size is given and is equal or lower than $200 \mu$ \\
\hline ID & In vivo study \\
\hline IE & Humans study \\
\hline IF & Sample size (teeth) is given \\
\hline IG1* & Presents the root canal classification (Vertucci or Weine) \\
\hline IG2* & Presents the number of root canals \\
\hline IG3* & Presents the number of roots \\
\hline IH & Maxillary first and/or second premolars \\
\hline II & Country of origin is given \\
\hline JBI & JBI Critical Appraisal equal or superior to $50 \%$ \\
\hline Code & Exclusion \\
\hline EA & Review studies \\
\hline EB & Case report \\
\hline EC & $\begin{array}{l}\text { Sample has been partially analyzed in another included } \\
\text { study }\end{array}$ \\
\hline ED & Endodontic-treated teeth \\
\hline EE & Third molar \\
\hline EF & Deciduous dentition \\
\hline
\end{tabular}

* Present, at least, one of the inclusion codes

Briggs Institute (JBI) Critical Appraisal tool for systematic reviews of prevalence studies. For each relevant study, the JBI questions were scored as: "yes", "no", "unclear" or "not appli-

\section{Table I. Terms used in each electronic database}

\begin{tabular}{|c|c|c|}
\hline Database & Terms used & Filters \\
\hline Pubmed & 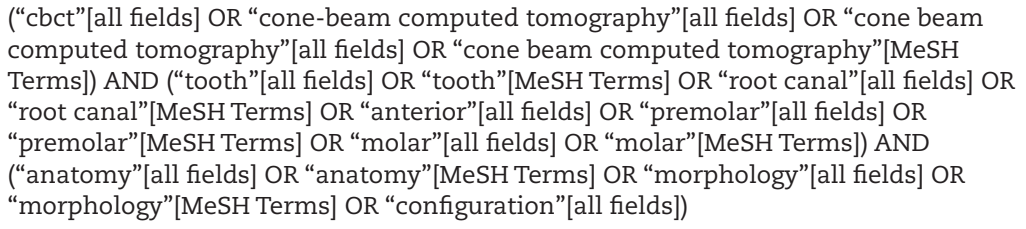 & $\begin{array}{l}\text { - Studies from January } 1990^{a} \text { to } \\
\text { August } 2018\end{array}$ \\
\hline ScienceDirect & "CBCT" AND "tooth" AND “morphology" & $\begin{array}{l}\text { - Studies from January } 1990^{a} \text { to } \\
\text { August } 2018 \\
\text { - Article type: "Research Articles" } \\
\text { and "Short Communications" }\end{array}$ \\
\hline Lilacs & $\begin{array}{l}\text { ((Cone Beam Computed Tomography) OR (CBCT)) AND ((tooth) OR (anterior) OR } \\
\text { (premolar) OR (molar)) AND ((anatomy) OR (morphology)) }\end{array}$ & $\begin{array}{l}\text { - Studies from January } 1990^{\mathrm{a}} \text { to } \\
\text { August } 2018\end{array}$ \\
\hline $\begin{array}{l}\text { Cochrane } \\
\text { Collaboration }\end{array}$ & "Endodontics" & $\begin{array}{l}\text { - Studies from January } 1990^{a} \text { to } \\
\text { August } 2018\end{array}$ \\
\hline
\end{tabular}

a Decade of CBCT introduction 
Table III. Joanna Briggs Institute (JBI) Critical Appraisal tool for systematic reviews of prevalence study questions

$\#$

1 Was the sample frame appropriate in addressing the target population?

2 Were study participants recruited in an appropriate way?

3 Was the sample size adequate?

$4 \quad$ Were the study subjects and setting described in detail?

5 Was data analysis conducted with sufficient coverage of the sample identified?

6 Were valid methods used for the identification of the condition?

7 Was the condition measured in a standard, reliable way for all participants? 8 Was there appropriate statistical analysis?
Cohen kappa inter-rater reliability between evaluators

9 Was the response rate adequate, and if not, was the low response rate managed appropriately?

Not applicable

cable". However, only positive results ("yes") were considered for the final score of this paper. This assessment was performed independently by two evaluators (JM and DM). Cohen kappa value was calculated in order to determine the inter-rater reliability between both evaluators. The final reliability results to each question are summarized in Table III. A good agreement was considered to be scores equal or above 0.61 .

The critical appraisal divergences were discussed until a final consensus was reached between both evaluators. Only the consensual agreement was considered for each of the final scores of the studies. This search was conducted between May 2018 and August of 2018 and no language restrictions were imposed. All studies available from January 1990 (decade of CBCT introduction) to August 2018 were taken into account.

\section{Statistical analysis}

For statistical purposes, considering that this review assessed the prevalence of a second root or root canal in maxillary premolars, 3-rooted or 3-canal configuration teeth were included in the second root and second root canal groups (multiple roots or root canals configurations).

The prevalence of a second root and second root canal in maxillary first and second premolars was calculated based on the proportions reported in the pooled studies. A random-effects model (Dersimonian-Laird test) using the OpenMeta [Analyst] v. 10.10 (http://www.cebm.brown.edu/openmeta/) software was used to process all data. The final primary outcomes were presented as odds ratios (OR) and proportions forest plots with a 95\% confidence interval (CI). $\mathrm{Tau}^{2}$ (estimate of between-study variance) was considered in order to assess the heterogeneity among studies. Q-Cochran test with Dersimonian and Laird (occurrence of heterogeneity) and the $\mathrm{I}^{2}$ statistic were used to measure the statistical heterogeneity of the proposed outcomes. The heterogeneity was categorized as "low" [25\%], "moderate" [50\%], or "high" [75\%]) depending on the $\mathrm{I}^{2}$ value (\%). Meta-regression analysis was used to assess possible sources of heterogeneity. ${ }^{17,18}$ The statistical significance was set at $\mathrm{p}<0.05$.

\section{Results}

Study selection, characteristic and risk of bias

The search strategy was able to identify 19 relevant studies in the electronic database $(n=17)$ and hand $(n=2)$ searches. Fourteen authors were contacted by email with 6 replies $(42.9 \%$ return rate) adding 2 more studies. Thus, from 21 studies submitted to full text analysis, 12 were excluded (Table IV) and 9, showing a global JBI score average of $82.5 \%$, were accepted in this review, and only one was submitted to qualitative synthesis only. ${ }^{19}$ Three studies were classified as having a moderate risk of bias (RoB), ${ }^{20-22}$ while the remaining papers $(n=6)$ were assessed as having a low RoB. According to the Joanna Briggs Institute levels of evidence, this review could be categorized as Level 4a (systematic review of descriptive studies). The PRISMA flow diagram is presented in Figure 1. The pooled studies reported data from 3,886 patients (1,744 males and 2,142 females) with an average age of 43.7 years determined by the 5 studies with available information. In order to achieve the review of primary outcomes, the data from 8,180 teeth (4,230 first premolars and 3,950 second premolars) were pooled together. Studies $(n=9)$ selected in this review included information from 5 countries (Brazil, China, Germany, Portugal and Spain) and were published in 3 different languages (English [ $n=7]$, Chinese $[n=1]$ and Portuguese [ $n=1]$ ). Table V summarizes the overall characteristics and results of the studies.

\section{Prevalence of second root and root canal according to teeth}

Taking in consideration the outcomes of 7 studies that addressed this topic and that were included in this review, the proportions of a second root were $43.2 \%$ (30.7\%-55.6\% CI 95\%) and $8.5 \%$ (4.9\%-12.2\% CI 95\%) for the maxillary first and second premolars, respectively. In terms of the prevalence of a second root canal, the overall results were $77.2 \%$ (66.0\%-88.4\% CI 95\%) for the first premolar and $43.9 \%$ (30.1\%-57.8\% CI 95\%) for the second premolar. Both root and root canal analysis showed high $\mathrm{I}^{2}$ values (above 96\%). A significant difference 
Table IV. List of the studies excluded from the review

\begin{tabular}{|c|c|c|c|}
\hline Study & $\begin{array}{l}\text { Inclusion factor } \\
\text { absent (code) }\end{array}$ & Excluded data & Reason \\
\hline Beshkenadze et al. $2015^{43}$ & IC & All & Does not state the voxel size \\
\hline Bulut et al. $2015^{44}$ & IC & All & Voxel size of $250 \mu$ \\
\hline Elkady et al. 201345 & JBI & All & JBI Critical Appraisal less than $50 \%$ \\
\hline Estrela et al. $2015^{46}$ & JBI & All & JBI Critical Appraisal less than $50 \%$ \\
\hline Felsypremila et al. $2015^{47}$ & IC & All & Does not state the voxel size \\
\hline Martins et al. 201748 & EC & All & Sample analyzed in another larger sample study (Martins et al. 2018a ${ }^{8}$ ) \\
\hline Mirzaie et al. 201249 & IB, IC & All & Does not state the voxel size or CBCT device \\
\hline Monsarrat et al. $2016^{50}$ & JBI & All & JBI Critical Appraisal less than $50 \%$ \\
\hline Nazeer et al. $2018^{51}$ & IC & All & Does not state the voxel size \\
\hline Ok et al. $2014^{52}$ & IC & All & Voxel size of $300 \mu$ \\
\hline Tian et al. $2012^{53}$ & JBI & All & JBI Critical Appraisal less than $50 \%$ \\
\hline Tofangchiha et al. $2018^{54}$ & IC & All & Does not state the voxel size \\
\hline
\end{tabular}

\section{Table V. Second root and second root canal prevalence in maxillary first and second premolars}

\begin{tabular}{|c|c|c|c|c|c|c|c|c|c|c|c|c|c|c|c|}
\hline $\begin{array}{l}\text { Author } \\
\text { Year }\end{array}$ & Country & $\begin{array}{l}\text { CBCT } \\
\text { device }\end{array}$ & $\begin{array}{c}\text { Voxel } \\
\text { size } \\
(\mu \mathrm{m})\end{array}$ & $\begin{array}{c}\text { Number } \\
\text { of } \\
\text { Subjects }\end{array}$ & $\begin{array}{l}\text { Males/ } \\
\text { Females }\end{array}$ & $\begin{array}{c}\text { Age } \\
\text { average }\end{array}$ & $\begin{array}{l}\text { Number } \\
\text { of Teeth }\end{array}$ & $\begin{array}{l}\text { Number } \\
\text { of Teeth } \\
\text { in Males }\end{array}$ & $\begin{array}{c}\text { Number of } \\
\text { Teeth in } \\
\text { Females }\end{array}$ & $\begin{array}{c}\text { Overall } \\
\text { Prevalence of the } \\
\text { Multiple-Roots } \\
\text { Config. }(\%)\end{array}$ & $\begin{array}{l}\text { Multiple- } \\
\text {-Roots } \\
\text { Prevalence } \\
\text { in males (\%) }\end{array}$ & $\begin{array}{c}\text { Multiple- } \\
\text {-Roots } \\
\text { Prevalence in } \\
\text { Females (\%) }\end{array}$ & $\begin{array}{l}\text { Overall } \\
\text { Prevalence } \\
\text { of the } 2 \text { nd } \\
\text { canal (\%) }\end{array}$ & $\begin{array}{c}\text { 2nd canal } \\
\text { Prevalence } \\
\text { in males } \\
(\%)\end{array}$ & $\begin{array}{c}\text { 2nd canal } \\
\text { Prevalence } \\
\text { in Females } \\
(\%)\end{array}$ \\
\hline \multicolumn{16}{|c|}{ Maxillary first premolar } \\
\hline $\begin{array}{l}\text { Abella et al. } \\
2015^{10}\end{array}$ & Spain & Planmeca & $75 \mu$ & 620 & $362 / 258$ & $n / a$ & 430 & 212 & 218 & $232(53.9)$ & $119(56.1)$ & $113(51.8)$ & $232(54.0)$ & $\mathrm{n} / \mathrm{a}$ & $n / a$ \\
\hline $\begin{array}{l}\text { Bürklein et al. } \\
2017^{14}\end{array}$ & Germany & Planmeca & $200 \mu$ & 700 & $315 / 385$ & $n / a$ & 644 & 302 & 342 & $410(63.6)$ & $224(74.1)$ & $188(55.0)$ & $582(90.4)$ & $284(94.0)$ & $298(87.1)$ \\
\hline Caputo $2014^{30}$ & Brazil & Gendex & $200 \mu$ & 264 & $120 / 144$ & 48.9 & 381 & 176 & 205 & $213(55.9)$ & $120(68.2)$ & $93(45.4)$ & $171(44.9)$ & $60(34.1)$ & $111(54.1)$ \\
\hline Gu et al. $2011^{20}$ & China & Galileos & $125 \mu$ & 500 & $246 / 254$ & 39.2 & 436 & 203 & 233 & $132(30.3)$ & $80(39.4)$ & $52(22.3)$ & $\mathrm{n} / \mathrm{a}$ & $n / a$ & $\mathrm{n} / \mathrm{a}$ \\
\hline Li et al. $2018^{21}$ & China & Planmeca & $75 \mu$ & 774 & $276 / 498$ & $n / a$ & 1387 & $\mathrm{n} / \mathrm{a}$ & $n / a$ & $420(30.3)$ & $\mathrm{n} / \mathrm{a}$ & $\mathrm{n} / \mathrm{a}$ & $1224(88.2)$ & $\mathrm{n} / \mathrm{a}$ & $n / a$ \\
\hline $\begin{array}{l}\text { Martins et al. } \\
2018 a^{* 8}\end{array}$ & China & Carestream & $200 \mu$ & 120 & $54 / 66$ & 28.0 & 238 & 107 & 131 & $40(16.8)$ & $24(22.4)$ & $16(12.2)$ & $209(87.8)$ & $98(91.6)$ & $111(84.7)$ \\
\hline $\begin{array}{l}\text { Martins et al. } \\
2018 c^{23}\end{array}$ & Portugal & Planmeca & $200 \mu$ & 670 & $243 / 427$ & 51.0 & 714 & 269 & 445 & $366(51.2)$ & $176(65.4)$ & $190(42.7)$ & $690(96.6)$ & $267(99.3)$ & $423(95.1)$ \\
\hline \multicolumn{16}{|c|}{ Maxillary second premolar } \\
\hline $\begin{array}{l}\text { Abella et al. } \\
2015^{10}\end{array}$ & Spain & Planmeca & $75 \mu$ & 620 & $362 / 258$ & $n / a$ & 374 & 204 & 170 & $64(17.1)$ & $34(16.7)$ & $30(17.6)$ & $64(17.1)$ & $n / a$ & $\mathrm{n} / \mathrm{a}$ \\
\hline $\begin{array}{l}\text { Bürklein et al. } \\
2017^{14}\end{array}$ & Germany & Planmeca & $200 \mu$ & 700 & $315 / 385$ & $n / a$ & 512 & 235 & 277 & $89(17.4)$ & $50(21.3)$ & $39(14.1)$ & $291(56.9)$ & $152(64.7)$ & $139(50.2)$ \\
\hline Gu et al. $2011^{20}$ & China & Galileos & $125 \mu$ & 500 & $246 / 254$ & 39.2 & 412 & 186 & 226 & $17(4.1)$ & $8(4.3)$ & $9(4.0)$ & $\mathrm{n} / \mathrm{a}$ & $\mathrm{n} / \mathrm{a}$ & $\mathrm{n} / \mathrm{a}$ \\
\hline Li et al. $2018^{21}$ & China & Planmeca & $75 \mu$ & 774 & $276 / 498$ & $n / a$ & 1403 & $\mathrm{n} / \mathrm{a}$ & $\mathrm{n} / \mathrm{a}$ & $53(3.8)$ & $\mathrm{n} / \mathrm{a}$ & $\mathrm{n} / \mathrm{a}$ & $697(49.7)$ & $\mathrm{n} / \mathrm{a}$ & $\mathrm{n} / \mathrm{a}$ \\
\hline $\begin{array}{l}\text { Martins et al. } \\
2018 a^{* 8}\end{array}$ & China & Carestream & $200 \mu$ & 120 & $54 / 66$ & 28.0 & 239 & 108 & 131 & $2(0.8)$ & $0(0.0)$ & $2(1.5)$ & $60(25.1)$ & $35(32.4)$ & $25(19.1)$ \\
\hline $\begin{array}{l}\text { Martins et al. } \\
2018 c^{23}\end{array}$ & Portugal & Planmeca & $200 \mu$ & 670 & $243 / 427$ & 51.0 & 618 & 249 & 369 & $33(5.3)$ & $18(7.2)$ & $15(4.1)$ & $372(60.2)$ & $179(71.9)$ & $193(52.3)$ \\
\hline Yang et al. $2014^{22}$ & China & Galileos & $125 \mu$ & 238 & $128 / 110$ & 35.0 & 392 & 197 & 195 & $53(13.5)$ & $28(14.3)$ & $25(12.8)$ & $214(54.6)$ & $\mathrm{n} / \mathrm{a}$ & $\mathrm{n} / \mathrm{a}$ \\
\hline
\end{tabular}

$\mathrm{n} / \mathrm{a}$ not available

* Information not available in the original manuscript, but provided by the author following contact 

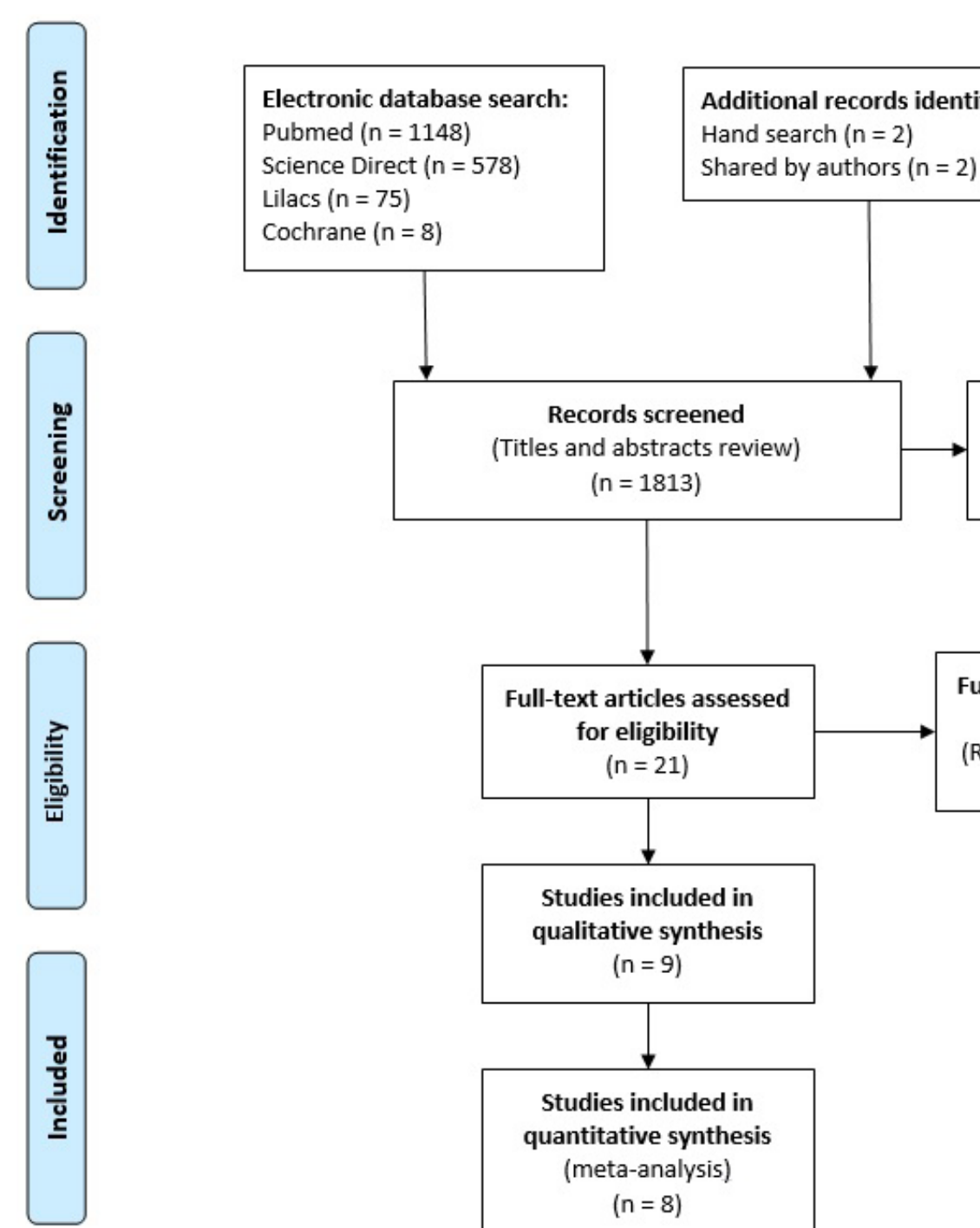

Hand search $(\mathrm{n}=2)$

Shared by authors $(n=2)$
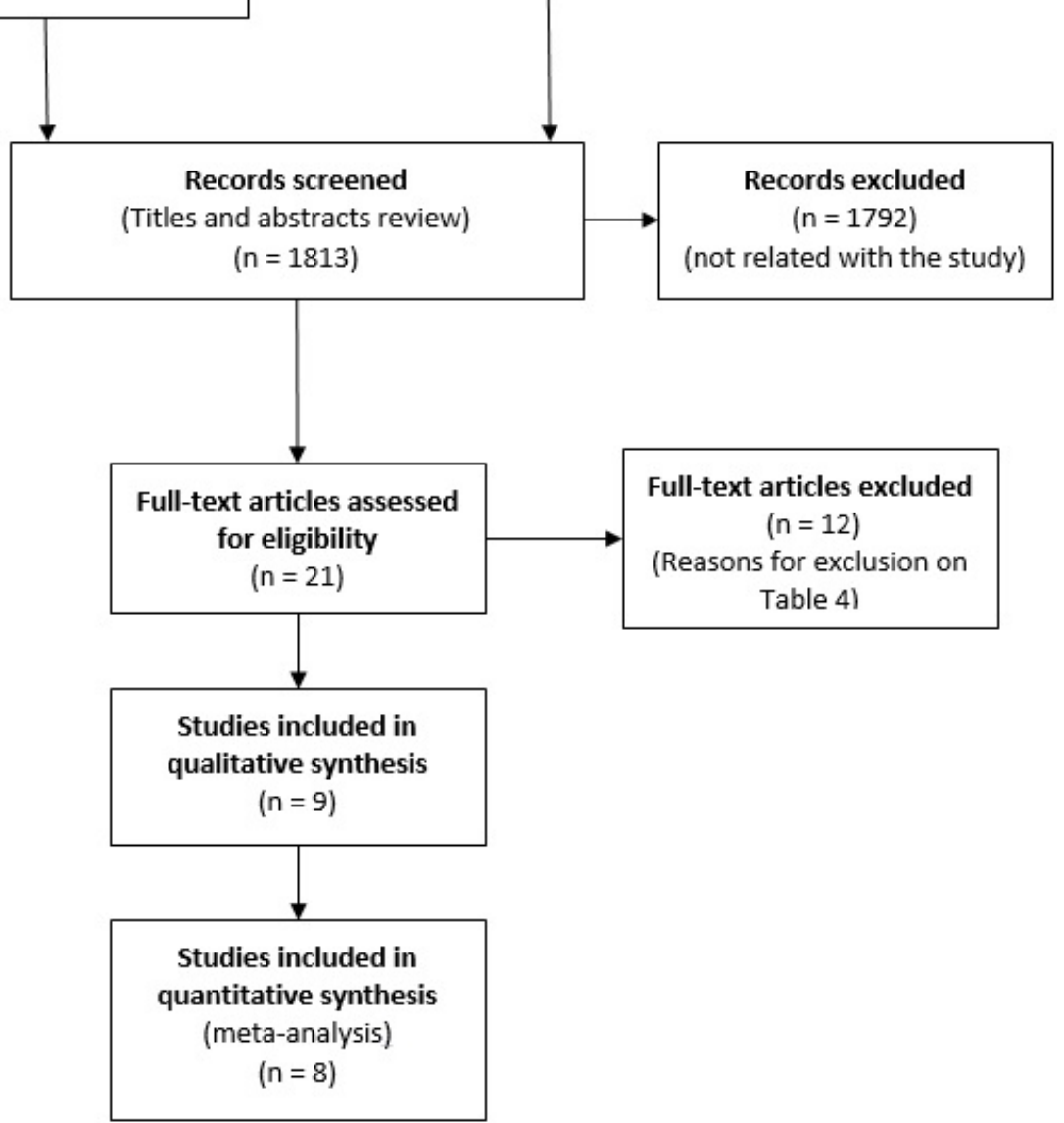

Figure 1. Review search strategy PRISMA flowchart

was found between both premolars, for either root or root canal prevalence $(\mathrm{p}<0.05)$ (Figure 2).

\section{Prevalence of second root and root canal according to gender}

The proportion of the second root according to gender was addressed in 5 studies (representing 6 sub-populations) in each one of the premolar group. Although no statistical difference was observed between genders, males presented a higher proportion of second root than females for both premolar teeth. These results were associated with high heterogeneity values $\left(\mathrm{I}^{2}=97.93 \%\right.$ and $93.87 \%$ for the first and second premolar, respectively) (Figures 3 and 4). However, a significant difference between genders was noted in the odds ratio (OR) for having a second root in the maxillary first premolars $(\mathrm{OR}=$ $2.111 ; 1.645-2.708$ CI 95\%) $(\mathrm{p}<0.05)$ with a moderate heterogeneity $\left(\mathrm{Tau}^{2}=0.053 ; \mathrm{Chi}^{2}=11.495, \mathrm{df}=5\right.$ [p = 0.042]; $\left.\mathrm{I}^{2}=56.50 \%\right)$ (Figure 3 ). In the second premolars, males showed higher odds (1.247; 0.958-1.624 CI 95\%) of presenting a second root than females, with a low heterogeneity $\left(\mathrm{Tau}^{2}=0.000 ; \mathrm{Chi}^{2}=\right.$
4.175, $\left.\mathrm{df}=4[\mathrm{p}=0.524] ; \mathrm{I}^{2}=0 \%\right)$, but without statistical significant difference $(p>0.05)$ (Figure 4$)$.

A meta-regression was conducted to assess geographic region as possible source of the explainable heterogeneity of second root prevalence in both maxillary premolar results. The region meta-regression omnibus $p$-values were $<0.001$ and 0.028 for the first and second maxillary premolars, respectively, revealing that the geographic region could be one possible source of the heterogeneity in the obtained results.

Regarding the prevalence of a second root canal, very few studies made this information available. Three studies (representing 4 sub-populations) reported the proportions according to gender in the maxillary first premolars. In 3 of those sub-population groups, a high percentage frequency of a second canal was observed in males. ${ }^{8,14,23}$ For the second premolar, 2 studies (representing 3 sub-populations) compared gender prevalence, with all sub-populations showing high proportions of a second root canal in males. The data regarding the presence of a second canal in the maxillary premolars between 


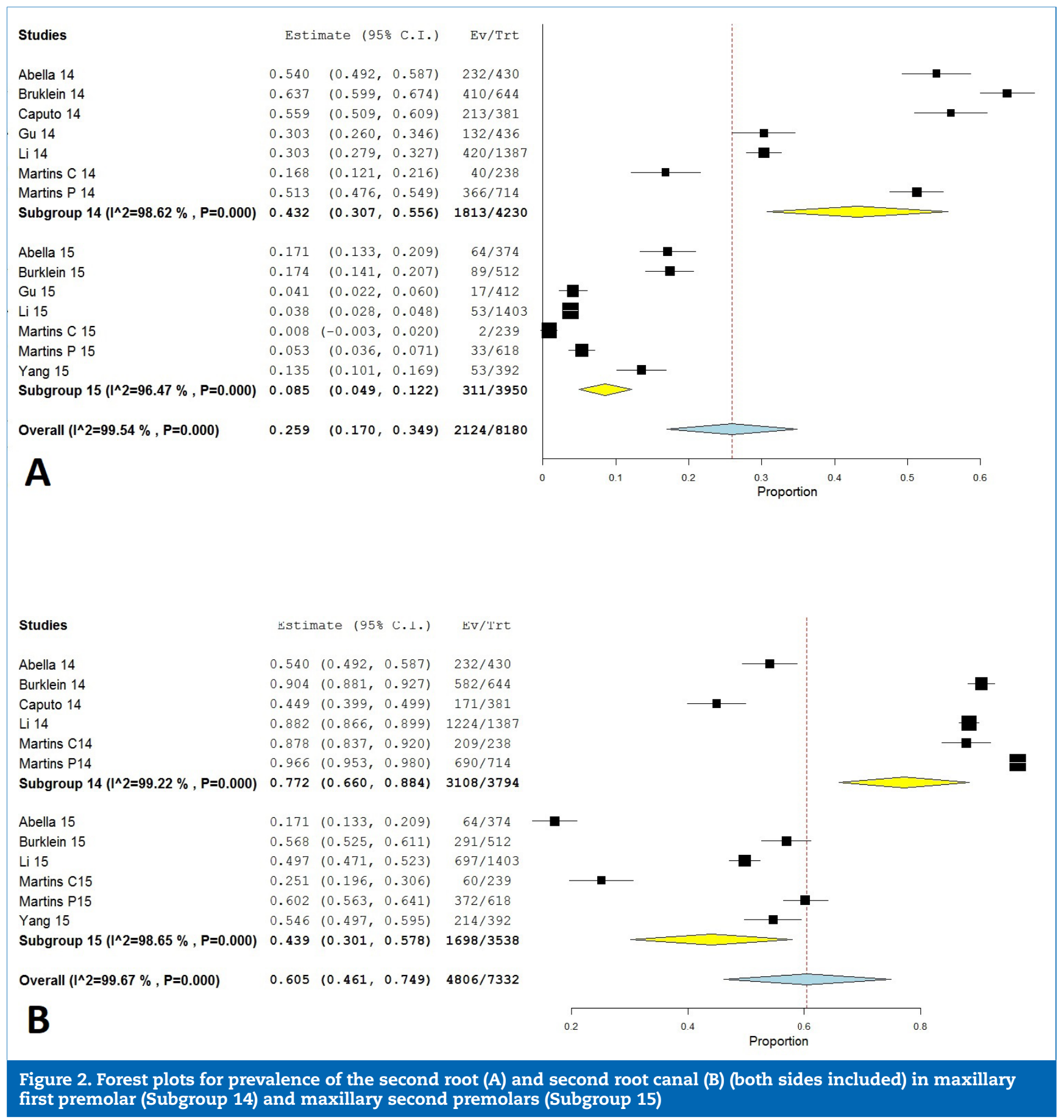

genders was not pooled into a meta-analysis due to the limited number of studies available.

Prevalence of second root and root canal according to geographic region

Seven studies from 3 geographic regions (3 studies from Europe, 3 studies from China and 1 study from South America) reported the prevalence of a second root in the maxillary first premolars which were pooled in a meta-analysis. The highest proportion (56.3\%; 48.4\%-64.2\% CI 95\%) was found in Europe, while the lowest proportion $(26.0 \% ; 18.2 \%-33.8 \%$ CI 95\%) was identified in the Chinese sub-group. Significant differences were noted between regions $(p<0.05)$ (Figure 5). For the second premolar, 6 studies from 2 geographic regions (3 studies from Europe, 3 studies from China) were identified. The percentage of a second root was higher in Europe (13.2\%; 4.2\%-22.2\% CI 95\%) when compared to China (5.2\%; 1.9\%-8.4\% CI 95\%), although no statistical significance was found ( $>>0.05$ ) (Figure 6). High $\mathrm{I}^{2}$ values were associated with these results. Regional meta-regression omnibus $p$-values were $<0.001$ and 0.050 for maxillary first and second premolars, respectively, and did not exclude region as one possible source of heterogeneity in the second root results. 


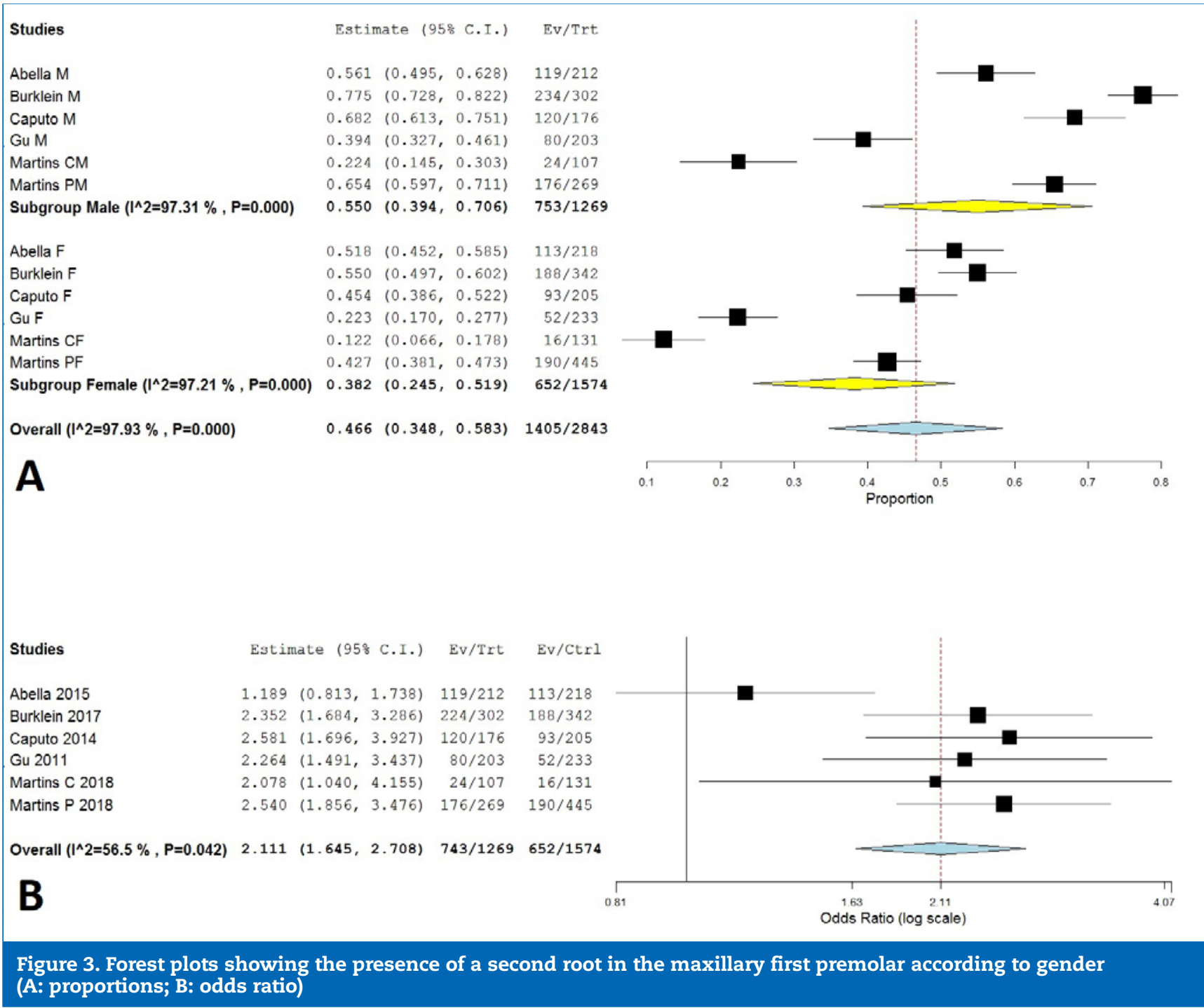

Six studies addressed the prevalence of a second root canal in each group of teeth, according to geographic regions. The results between Europe and China sub-groups were balanced with no significant difference between them for both groups of teeth ( $p>0.05$ ) (Figures 5 and 6$)$. The only statistical difference was detected for the maxillary first premolar which showed a significantly lower proportion of a second canal in a South America sub-group (one single study available) when compared to the other regions (Figure 5). High $\mathrm{I}^{2}$ values were also associated with these results. The geographic region meta-regression omnibus $\mathrm{p}$-values confirmed this variable as a possible source in explaining heterogeneity in the second canal results for the first premolar (0.025), but not for the second premolar (0.912).

Prevalence of second root and root canal according to age groups It was not possible to identify a study in this review in which differences in the number of roots of maxillary premolars among age groups was evaluated. However, a single study (19) showed a tendency towards an increase in the percentage of second canals over the years in both teeth, mostly in the maxillary second premolar.
Prevalence of second root and root canal according to voxel imaging size

A meta-regression was conducted in order to assess the voxel imaging size as a possible source in explaining heterogeneity. The graphic analysis revealed an almost constant prevalence of both second root and second root canal in either maxillary first or second premolars (Figures 7 and 8). The omnibus p-values were 0.588 (first premolar) and 0.671 (second premolars) for the second root results, and 0.599 (first premolar) and 0.395 (second premolar) for the second canal outcomes, excluding CBCT voxel imaging size as possible source of heterogeneity in the results.

\section{Discussion}

Populations from different geographic regions and ethnic backgrounds may present different anatomic characteristics, which is a condition that might be explained anthropologically. ${ }^{24}$ In the medical field, the link between anatomic traits or specific diseases and patients from different demographic backgrounds have also been well documented. ${ }^{25-27}$ In dentist- 


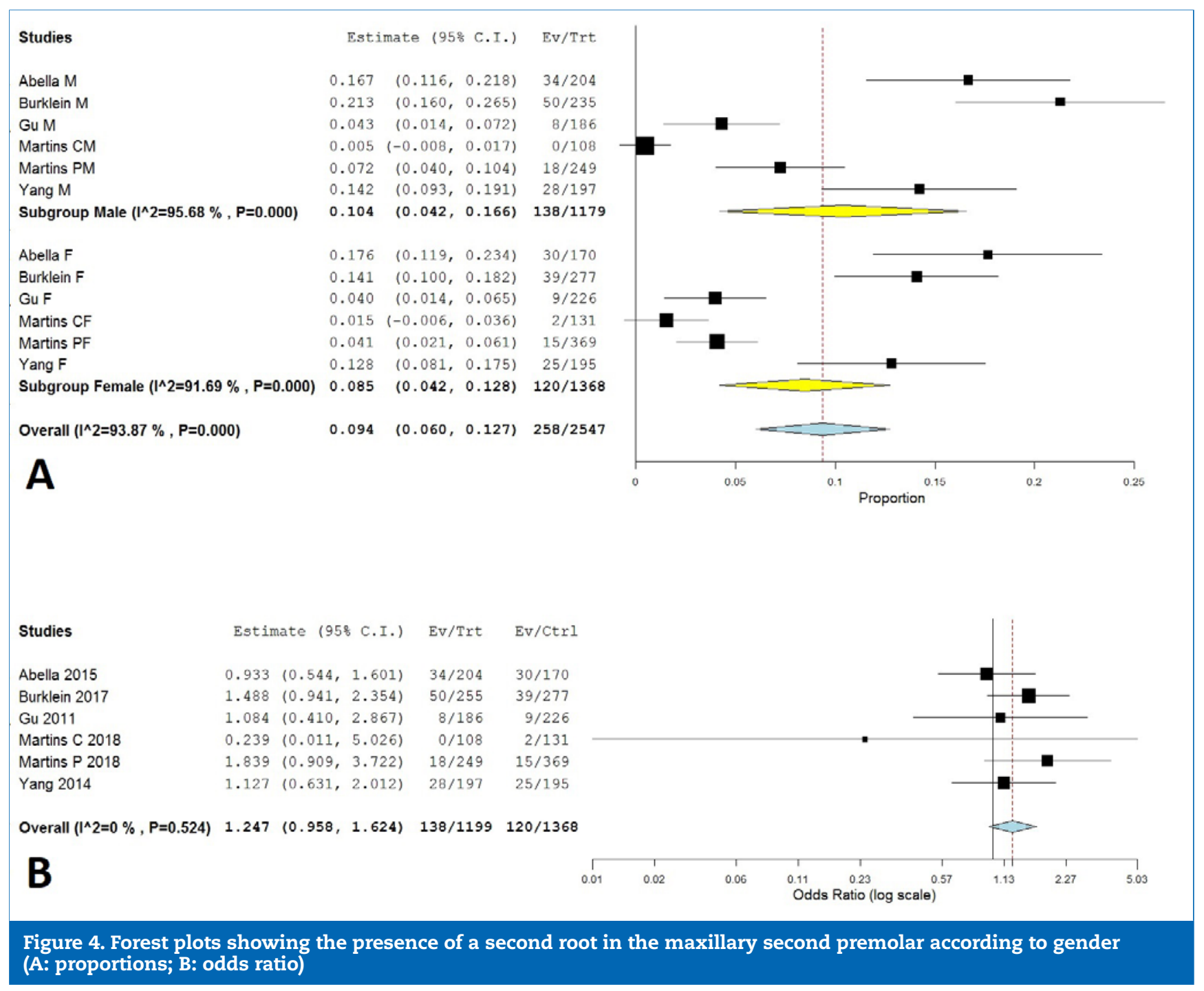

ry, some studies have also found a correlation between morphologic characteristics and different ethnic backgrounds. $8,28,29$ However, this topic is still not fully addressed or understood in dentistry.

The overall outcomes of this study for the presence of a second root in the maxillary first premolar showed a worldwide prevalence of $43.2 \%$. The highest proportion was found in Germany (63.7\%) ${ }^{14}$ and the lowest in China (16.8\%). ${ }^{8}$ For the second premolar, global prevalence of a second root was $8.5 \%$, with the highest $(17.4 \%)$ and the lowest $(0.8 \%)$ proportions reported in Germany ${ }^{14}$ and China, ${ }^{8}$ respectively. In relation to the prevalence of the second root canal, the mean global percentages were $77.2 \%$ and $43.9 \%$ for the first and second premolars, respectively. The highest prevalence was identified in Portugal for both tooth groups $(96.6 \%$ and $60.2 \%$ for first and second premolars, respectively), ${ }^{8}$ while the lowest proportions were found in Brazil (44.9\% for the first premolar) ${ }^{30}$ and Spain $(17.1 \%$ for the second premolar). ${ }^{10}$ The results of the polled papers were associated with high $\mathrm{I}^{2}$ values (above $96 \%$ ) for both tooth groups, which may be justified by the heterogeneity of the demographic data. Differences observed in the overall prevalence of a second root and second root canal between premo- lar groups were considered significantly different, and the first null hypothesis was rejected.

Although meta-analysis did not identified significant differences in the second root prevalence between males and females, it could be observed a tendency for higher percentages, for both tooth groups, as well as, significantly higher odds (OR 2.11) in males than females for the first premolar (Figure 3). Despite, odds ratios were also higher in the second premolar for males (OR 1.247), no statistical difference was found. Therefore, the second null hypothesis was rejected for the maxillary first premolar, but not for the second premolar. Unfortunately, it was not possible to test the second null hypothesis for the presence of a second root canal in any of the premolar groups because of the limited number of studies available.

Meta-regression analysis was not able to exclude geographic region as a possible source of heterogeneity, which may partially justify the high $\mathrm{I}^{2}$ values obtained in the geographic region and gender analysis. Moreover, significant differences between geographic regions were found for both second root and second root canal prevalence in maxillary first premolars (Figure 5), while no difference was noted between 


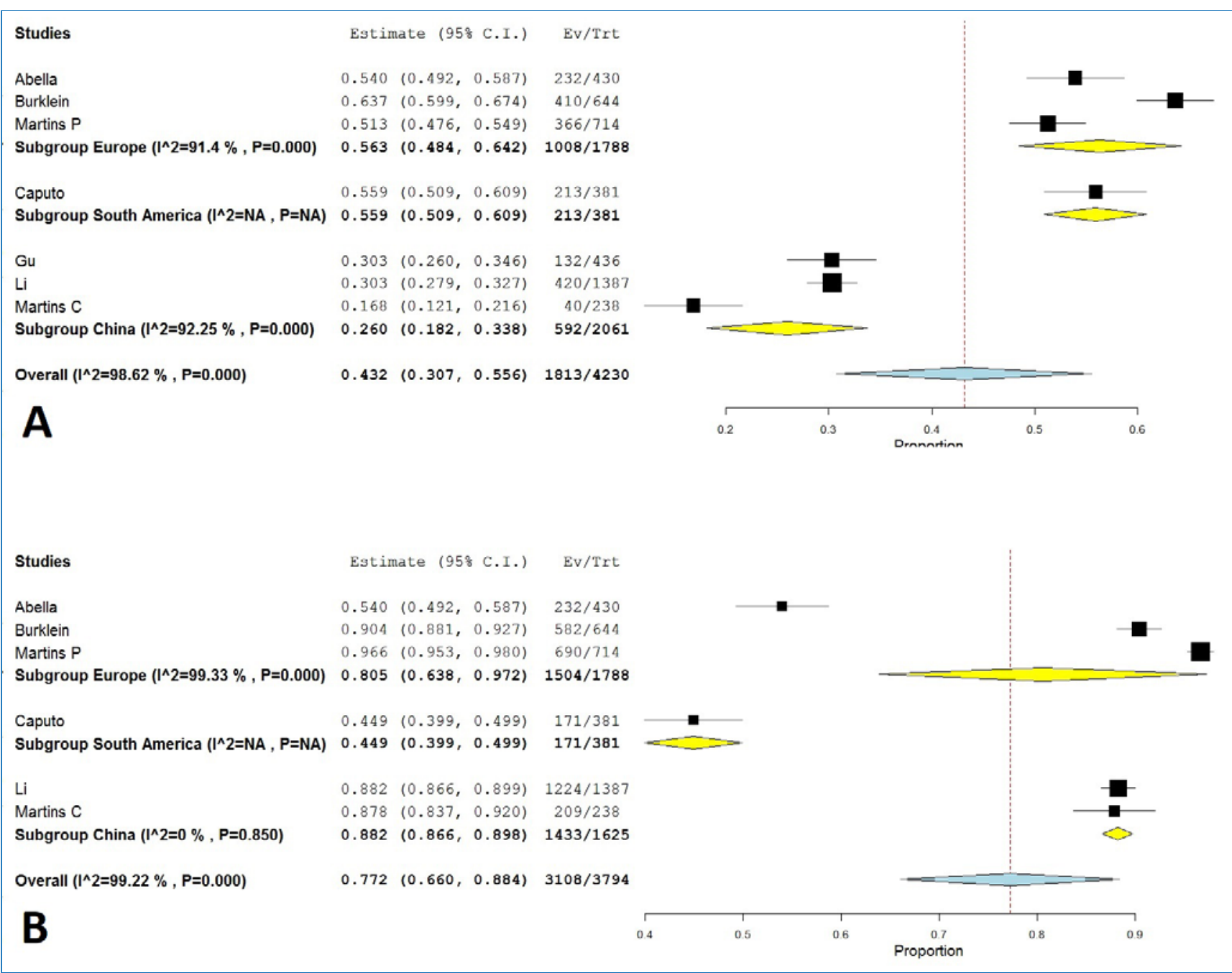

Figure 5. Forest plots showing the presence of a second root (A) and second root canal (B) in the maxillary first premolar according to geographic region

regions in any of the outcomes in the second premolar (Figure 6). Consequently, the third null hypothesis was rejected for the first premolar and accepted for the second premolar.

Sexual dimorphism and differences between geographic regions or ethnic groups are difficult to understand based only on the available dental literature. Anthropological investigations indicate that the origin of modern humans might have occurred in Africa, most probably in Kenya. ${ }^{31}$ During the diasporas, a movement that lead to the inhabiting of the world by our ancestral humans, three main ethnic groups were formed, one of which led to Euro-Asia (originating in the Caucasians), another to Asia and the last remaining in Africa. ${ }^{31}$ Genetic drift, gene flow, and environmental adaptations are evolutionary processes which might have led to differences in tooth phenotype evolution in different population groups. ${ }^{32}$ Anthropological studies noted that the number of roots in maxillary premolars has decreased with the appearance of Homo sapiens. It has been demonstrated that modern humans show high proportions of single-rooted morphology in maxillary premolars compared to Australopithecus (the ascendant of Homo genera) which had mostly two-rooted configurations in this group of teeth. ${ }^{33}$ In premolar crown morphology there are also sim- ilarities and differences between ancestral species from several locations and modern humans. An anthropological study from Xing et al. ${ }^{34}$ compared several landmarks in the crown of mandibular premolar teeth between Zhoukoudian (a cave system in the sub-urban area of Beijing, China) Homo erectus, Asian Homo erectus (outside Zhoukoudian), early African Homo specimens, European Pleistocene (Ice age) fossil hominids, and modern Chinese. Authors concluded that several primitive hominid traits were preserved in Zhoukoudian specimens when compared to their ancestors, and a high degree of diversity was already noted with European ancestral specimens. The modern Chinese lost some traits or express them in a less evident way when compared to Chinese Zhoukoudian Homo erectus. These differences has been considered as signs of evolution. The morphological features of both premolar and molar teeth in modern humans most likely reflect an adaptation to diet $^{35}$ and environment that could have occurred a long time ago and were modelled over the years. Concerning the sexual dimorphism, several studies indicated that males used to have longer or more roots than females. ${ }^{36,37}$ This high prevalence in males was observed in this review and might be explained because of the largest maxillary arch length present in males ${ }^{38}$ 


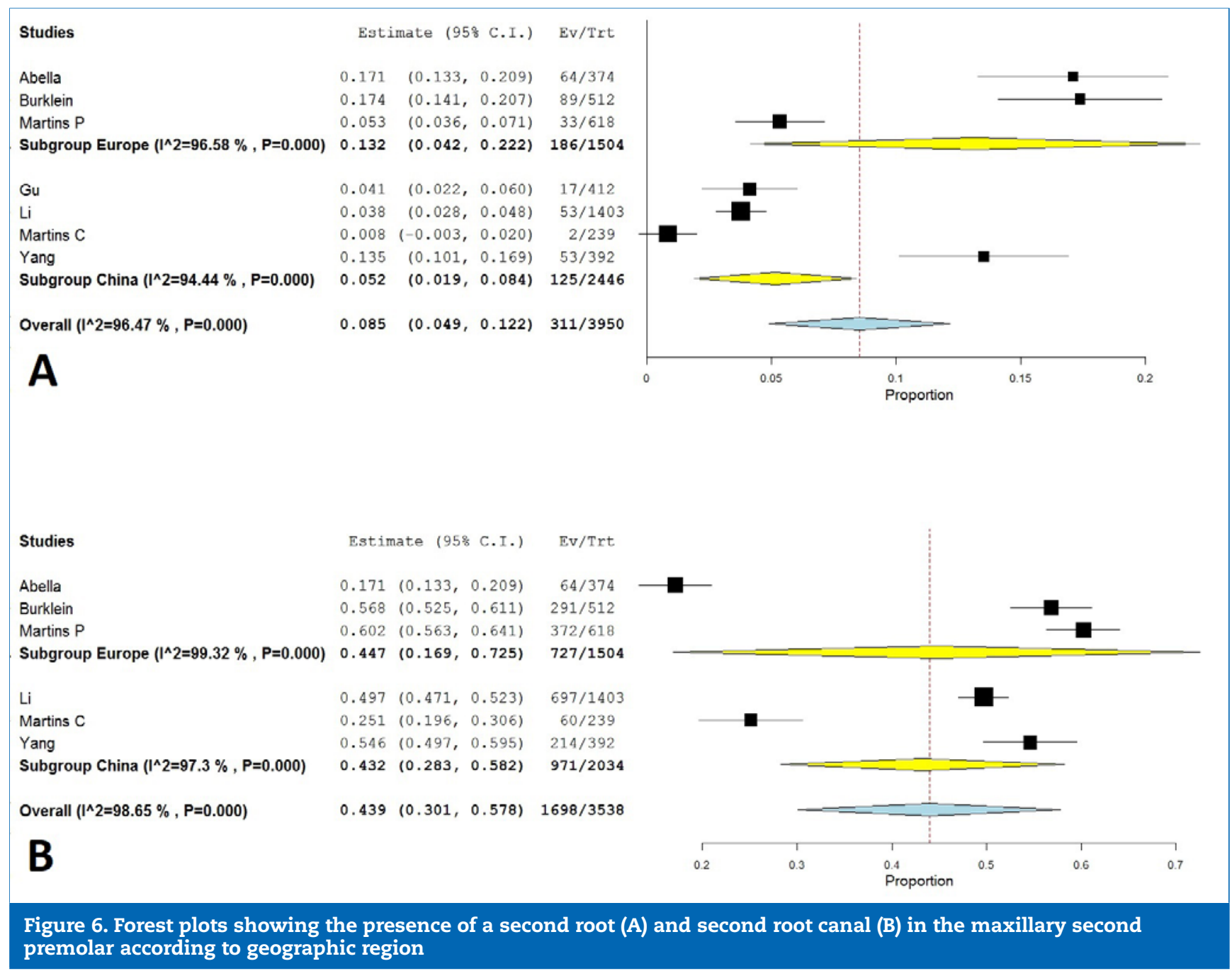

or to the influence of the chromosomeY on root length growth, which is greater than that of the chromosome $\mathrm{X} .{ }^{39}$

In terms of the influence of aging in the number of roots and root canals in maxillary premolars, very little information is available, and it was not possible to test the fourth null hypothesis. Although the number of roots is not supposed to change over the years, since they are formed during the embryological stage of tooth development and are expected to remain similar in their outer morphology over time, the morphology of the root canal may indeed change due to the deposition of dentin as a result of external stimuli ${ }^{40}$ or natural aging. ${ }^{41,42}$ According to Martins et al., ${ }^{19}$ a replacement of the Vertucci's Type I (1-1) configuration by Vertucci's Type II (2-1) may happen in older patients, mainly in the maxillary second premolar. This could be associated to the coronal deposition of secondary dentin which tends to split a long oval axial canal into two, following dentin deposition in the center of the canal. ${ }^{42}$ However, additional studies are required to confirm this data.

High heterogeneity was noted in some of the data polled into meta-analysis. This might be a result of the influence of the demographic characteristics of each study, since at least gender and geographic region might partially explain observer heterogeneity, but may also be due to the observer assess- ment and outcome methods. In order to minimize a part of the heterogeneity, studies with high RoB were excluded and a stratification analysis was conducted in order to isolate, as far as possible, each variable to be assessed. Funnel plots were not calculated due to the small number of available studies. Although every effort was made to control the internal validity of the review by excluding high RoB studies, the external validity (extrapolation to overall population) was still difficult to perform since the outcomes appear to be associated with the internal characteristics of the population being studied.

In this review, one of the limitations was the small number of studies available which did not allow to test all the hypothesis, reducing the strength of the results. Another limitation was the high heterogeneity observed, which might be partially explained by the results themselves, and the low level of evidence (Level 4 a) related to the review of observational studies. On the other hand, a major advantage could be considered the possibility to assess only in vivo studies, representing an approximation to the clinical conditions.

Future research should more thoroughly address the aging and gender effect on second root canal prevalence in order to strengthen the limited date available in the literature. Besides, further studies on the prevalence of root and root canals using in vivo CBCT technology should also include detailed informa- 


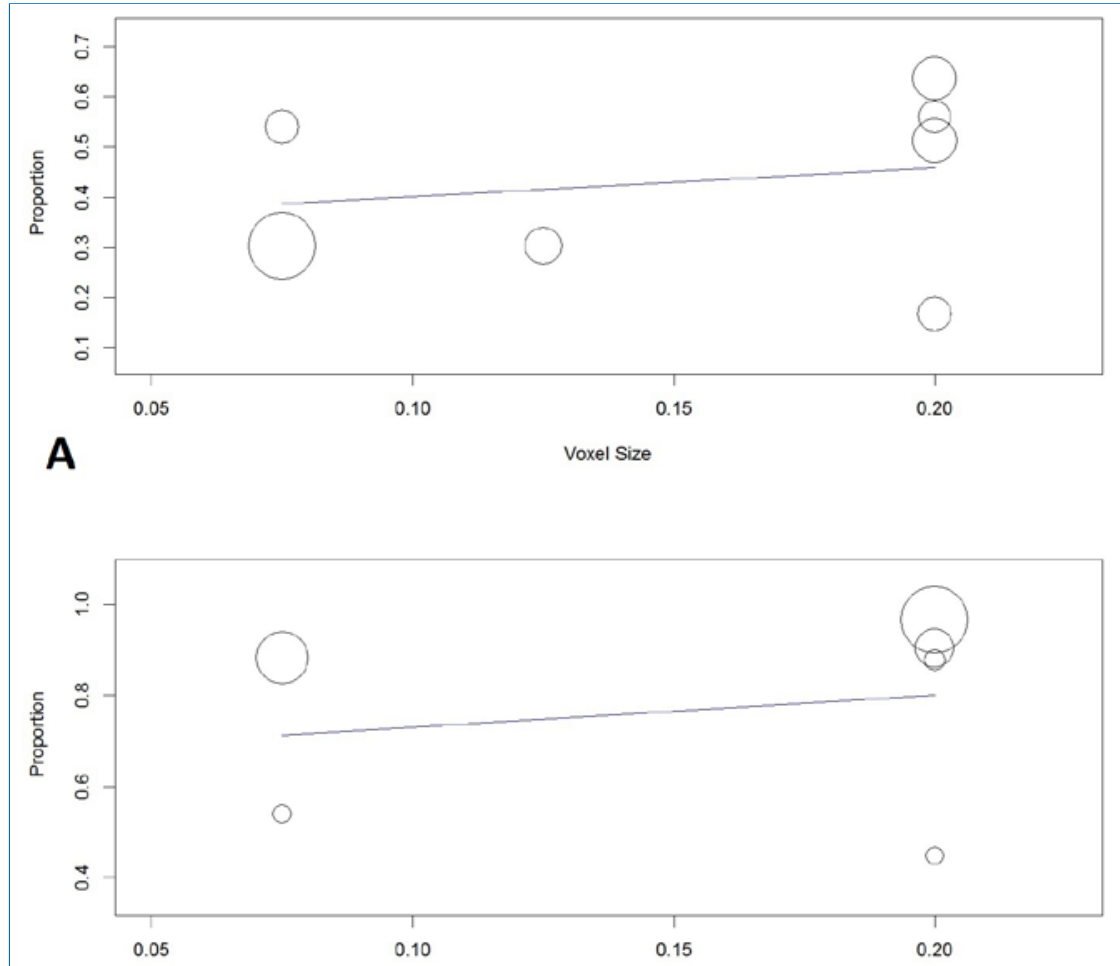

B

Voxel Size

Figure 7. Voxel size meta-regression for studies reporting on second root (A) and second root canal (B) on maxillary first premolars

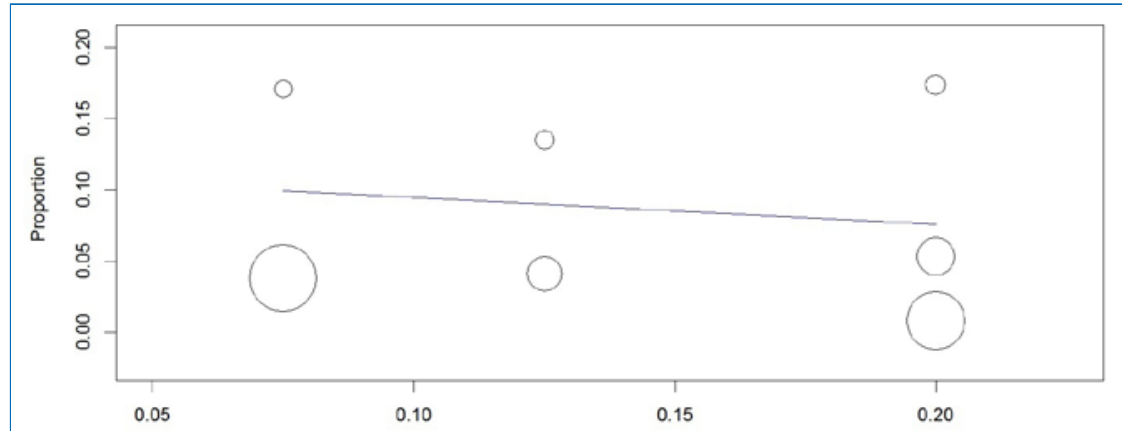

A

Voxel Size

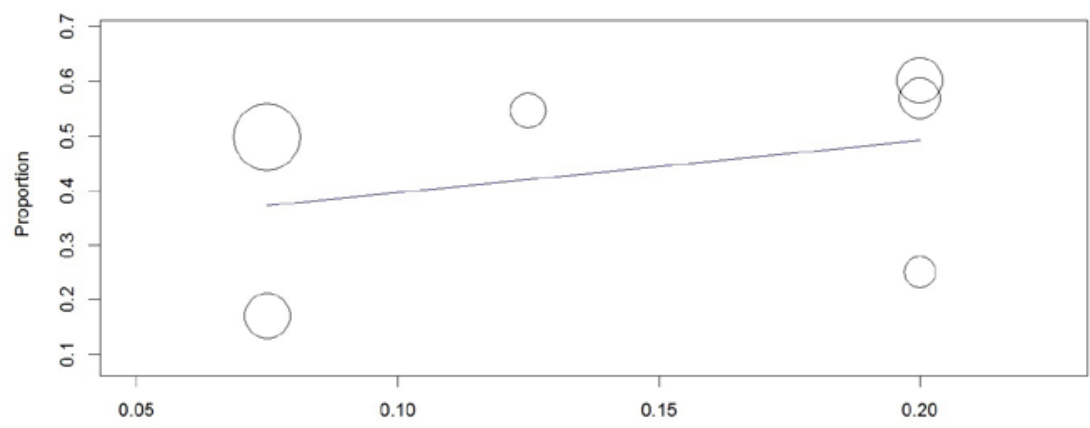

B

Voxel Size

Figure 8. Voxel size meta-regression for studies reporting on second root (A) and second root canal (B) on maxillary second premolars 
tion regarding population demographics. Therefore, the development of cross-sectional study guidelines for tooth morphology assessment is of utmost importance.

\section{Conclusions}

Number of roots and root canals in maxillary first and second premolars may vary. In this systematic review, 9 studies assessing were polled together to analyze the anatomy of maxillary premolar teeth by means of CBCT imaging. Overall prevalence of a second root and second root canal were $43.2 \%$ and $77.2 \%$ for the maxillary first premolar, and $8.5 \%$ and $43.9 \%$ for the second premolar. Significant differences were noted for both anatomic features between tooth groups. Males showed significantly higher odds $(\mathrm{OR}=2.111)$ of presenting a second root in the first premolar than females. The maxillary first premolar presented significant differences between geographic regions for both number of roots and root canals.

\section{Ethical disclosures}

Protection of human and animal subjects. The authors declare that no experiments were performed on humans or animals for this study.

Confidentiality of data. The authors declare that no patient data appear in this article.

Right to privacy and informed consent. The authors declare that no patient data appear in this article.

\section{Conflict of interest}

The authors have no conflicts of interest to declare.

\section{REFERENCES}

1. Sert S, Bayirli GS. Evaluation of the root canal configurations of the mandibular and maxillary permanent teeth by gender in the Turkish population. J Endod 2004;30:391-8.

2. Vertucci FJ. Root canal anatomy of the human permanent teeth. Oral Surg Oral Med Oral Pathol 1984;58:589-99.

3. Costa F, Pacheco-Yanes J, Siqueira JF, Jr., Oliveira ACS, Gazzaneo I, Amorim CA, et al. Association between missed canals and apical periodontitis. Int Endod J 2019;52:400-6.

4. Karabucak B, Bunes A, Chehoud C, Kohli MR, Setzer F. Prevalence of Apical Periodontitis in Endodontically Treated Premolars and Molars with Untreated Canal: A Cone-beam Computed Tomography Study. J Endod 2016;42:538-41.

5. Lyra CM, Delai D, Pereira KC, Pereira GM, Pasternak Junior B, Oliveira CA. Morphology of Mesiobuccal Root Canals of Maxillary First Molars: a comparison of CBCT scanning and Cross-sectioning. Braz Dent J 2015;26:525-9.

6. Ordinola-Zapata R, Martins JNR, Bramante CM, Villas-Boas $\mathrm{MH}$, Duarte $\mathrm{MH}$, Versiani MA. Morphological evaluation of maxillary second molars with fused roots: a micro-CT study. Int Endod J 2017;50:1192-200.

7. Martins JNR, Versiani M. CBCT and Micro-CT on the study of root canal anatomy. In: Versiani M, Basrani B, Sousa-Neto M, editors. The root canal anatomy in permanent dentition. Switzerland: Springer International Publishing 2018;89-180.

8. Martins JNR, Gu Y, Marques D, Francisco H, Carames J. Differences on the Root and Root Canal Morphologies between Asian and White Ethnic Groups Analyzed by Cone-beam Computed Tomography. J Endod 2018;44:1096$-104$.

9. Silva EJ, Nejaim Y, Silva AI, Haiter-Neto F, Zaia AA, Cohenca N. Evaluation of root canal configuration of maxillary molars in a Brazilian population using cone-beam computed tomographic imaging: an in vivo study. J Endod 2014;40:173-6.

10. Abella F, Teixido LM, Patel S, Sosa F, Duran-Sindreu F, Roig M. Cone-beam Computed Tomography Analysis of the Root Canal Morphology of Maxillary First and Second Premolars in a Spanish Population. J Endod 2015;41:1241-7.

11. Carns EJ, Skidmore AE. Configurations and deviations of root canals of maxillary first premolars. Oral Surg Oral Med Oral Pathol 1973;36:880-6.

12. Kartal N, Ozcelik B, Cimilli H. Root canal morphology of maxillary premolars. J Endod 1998;24:417-9.

13. Li J, Li L, Pan Y. Anatomic study of the buccal root with furcation groove and associated root canal shape in maxillary first premolars by using micro-computed tomography. J Endod 2013;39:265-8.

14. Burklein S, Heck R, Schafer E. Evaluation of the Root Canal Anatomy of Maxillary and Mandibular Premolars in a Selected German Population Using Cone-beam Computed Tomographic Data. J Endod 2017;43:1448-52.

15. Elnour M, Khabeer A, AlShwaimi E. Evaluation of root canal morphology of maxillary second premolars in a Saudi Arabian sub-population: An in vitro microcomputed tomography study. Saudi Dent J 2016;28:162-8.

16. Moher D, Liberati A, Tetzlaff J, Altman DG, Group P. Preferred reporting items for systematic reviews and meta-analyses: the PRISMA statement. PLoS Med 2009;6:e1000097.

17. Higgins JP, S. G. Cochrane handbook for systematic reviews of interventions. John Wiley \& Sons; 2011.

18. Higgins JP, Thompson SG. Quantifying heterogeneity in a meta-analysis. Stat Med 2002;21:1539-58.

19. Martins JNR, Ordinola-Zapata R, Marques D, Francisco H, Carames J. Differences in root canal system configuration in human permanent teeth within different age groups. Int Endod J 2018;51:931-41.

20. Gu Y, Zhou P, Ding Y. Detection of root variations of permanent teeth in a northwestern Chinese population by cone-beam computed tomography. Chin J Conserv Dent 2011;21:499-505.

21. Li YH, Bao SJ, Yang XW, Tian XM, Wei B, Zheng YL. Symmetry of root anatomy and root canal morphology in maxillary premolars analyzed using cone-beam computed tomography. Arch Oral Biol 2018;94:84-92.

22. Yang L, Chen X, Tian C, Han T, Wang Y. Use of cone-beam computed tomography to evaluate root canal morphology and locate root canal orifices of maxillary second premolars in a Chinese subpopulation. J Endod 2014;40:630-4.

23. Martins JNR, Marques D, Francisco H, Carames J. Gender influence on the number of roots and root canal system configuration in human permanent teeth of a Portuguese subpopulation. Quintessence Int 2018;49:103-11.

24. Irish J. Afridonty: the "Sub-Saharan African Dental Complex" revisited. In: Scott GR, Irish J, editors. Anthropological perspectives on tooth morphology. Genetics, evolution, variation. 1st ed. New York: Cambridge University Press 2013;278-95.

25. Shao H, Chen C, Scholl D, Faizan A, Chen AF. Tibial shaft anatomy differs between Caucasians and East Asian individuals. Knee Surg Sports Traumatol Arthrosc 2018;26:2758-65. 
26. Verkicharla PK, Suheimat M, Schmid KL, Atchison DA. Differences in retinal shape between East Asian and Caucasian eyes. Ophthalmic Physiol Opt 2017;37:275-83.

27. Vitalis A, Lip GY, Kay M, Vohra RK, Shantsila A. Ethnic differences in the prevalence of peripheral arterial disease: a systematic review and meta-analysis. Expert Rev Cardiovasc Ther 2017;15:327-38.

28. Guo J, Vahidnia A, Sedghizadeh P, Enciso R. Evaluation of root and canal morphology of maxillary permanent first molars in a North American population by cone-beam computed tomography. J Endod 2014;40:635-9.

29. Kato A, Ziegler A, Higuchi N, Nakata K, Nakamura H, Ohno N. Aetiology, incidence and morphology of the C-shaped root canal system and its impact on clinical endodontics. Int Endod J 2014;47:1012-33.

30. Caputo BV. Estudo da tomografia computadorizada de feixe cônico na avaliação morfológica de raizes e canais dos molares e pré molares da população brasileira [PhD]. São Paulo: Universidade de São Paulo; 2014.

31. Hanihara T. Geographic structure of dental variation in the major human populations of the world. In: Scott R, Irish J, editors. Anthropological perspectives on tooth morphology. Genetics, evolution, variation. 1st ed. New York: Cambridge University Press 2013;479-509.

32. Christy G, Turner I. Bite marks in tule quids: the life and times of a dental anthropologist. In: Scott R, Irish J, editors. Anthropological perspectiveson tooth morphology. Genetics,evolution, variation. New York: Cambridge University Press 2013;16-30.

33. Wood BA, Abbott SA, Uytterschaut H. Analysis of the dental morphology of Plio-Pleistocene hominids. IV. Mandibular postcanine root morphology. J Anat 1988;156:107-39.

34. Xing S, Zhou M, Liu W. Crown morphology and variation of the lower premolars of Zhoukoudian Homo erectus. Chinese Sci Bull 2009;54:3905-15.

35. Schroer K, Wood B. Evolution of hominin postcanine macromorphology: a comparative meta-analysis. In: Scott R, Irish J, editors. Anthropological perspectives on tooth morphology. Genetics, evolution, variation. New York: Cambridge University Press; 2013.

36. Lahdesmaki R, Alvesalo L. Root lengths in 47,XYY males' permanent teeth. J Dent Res 2004;83:771-5.

37. Selmer-Olsen R. An odontometric study on the Norwegian Lapps. Norway: University of Oslo; 1949.

38. Omar H, Alhajrasi M, Felemban N, Hassan A. Dental arch dimensions, form and tooth size ratio among a Saudi sample. Saudi Med J 2018;39:86-91.

39. Alvesalo L. The expression of human sex chromossome genes in oral and craniofacial growth. In: Scott GR, Irish J, editors. Anthropological perspectives on tooth morphology. Genetics, evolution, variation. 1st ed. New York: Cambridge University Press 2013;92-107.

40. Kuttler Y. Classification of dentin into primary, secondary and tertiary. Oral Surg Oral Med Oral Pathol 1959;12:996-9.
41. Gani OA, Boiero CF, Correa C, Masin I, Machado R, Silva EJ, et al. Morphological changes related to age in mesial root canals of permanent mandibular first molars. Acta Odontol Latinoam 2014;27:105-9.

42. Thomas RP, Moule AJ, Bryant R. Root canal morphology of maxillary permanent first molar teeth at various ages. Int Endod J 1993;26:257-67.

43. Beshkenadze E, Chipashvili N. Anatomo-morphological features of the root canal system in Georgian population - cone-beam computed tomography study. Georgian Med News 2015;247:7-14.

44. Bulut DG, Kose E, Ozcan G, Sekerci AE, Canger EM, Sisman Y. Evaluation of root morphology and root canal configuration of premolars in the Turkish individuals using cone beam computed tomography. Eur J Dent 2015;9:551-7.

45. Elkady A, Allouba K. Cone Beam computed tomography analysis of root and canal morphology of maxillary premolars in Saudi subpopulation. Egypt Dent J 2013;59:3419-29.

46. Estrela C, Bueno MR, Couto GS, Rabelo LE, Alencar AH, Silva RG, et al. Study of Root Canal Anatomy in Human Permanent Teeth in A Subpopulation of Brazil's Center Region Using Cone-Beam Computed Tomography - Part 1. Braz Dent J 2015;26:530-6.

47. Felsypremila G, Vinothkumar TS, Kandaswamy D. Anatomic symmetry of root and root canal morphology of posterior teeth in Indian subpopulation using cone beam computed tomography: A retrospective study. Eur J Dent 2015;9:500-7.

48. Martins JNR, Marques D, Mata A, Carames J. Root and root canal morphology of the permanent dentition in a Caucasian population: a cone-beam computed tomography study. Int Endod J 2017;50:1013-26.

49. Mirzaie M, Zaban T, Mohammadi V. Cone-beam Computed Tomography Study of Root Canals in a Hamadani Population in Iran. Avicenna J Dent Res 2012;4:25-31.

50. Monsarrat P, Arcaute B, Peters OA, Maury E, Telmon N, Georgelin-Gurgel M, et al. Interrelationships in the Variability of Root Canal Anatomy among the Permanent Teeth: A Full-Mouth Approach by Cone-Beam CT. PloS one 2016;11:e0165329.

51. Nazeer MR, Khan FR, Ghafoor R. Evaluation of root morphology and canal configuration of Maxillary Premolars in a sample of Pakistani population by using Cone Beam Computed Tomography. J Pak Med Assoc 2018;68:423-7.

52. Ok E, Altunsoy M, Nur BG, Aglarci OS, Colak M, Gungor E. A cone-beam computed tomography study of root canal morphology of maxillary and mandibular premolars in a Turkish population. Acta Odontol Scand 2014;72:701-6.

53. Tian YY, Guo B, Zhang R, Yu X, Wang H, Hu T, et al. Root and canal morphology of maxillary first premolars in a Chinese subpopulation evaluated using cone-beam computed tomography. Int Endod J 2012;45:996-1003.

54. Tofangchiha M, Bolbolian M, Ghasemi A. Evaluation of Root Canal Morphology of Maxillary First Premolars Using Cone Beam Computed Tomography. J Mas Dent Sch 2018;42:31-40. 